\title{
Investigations on the Use of Limitations to Freedom of Religion or Belief in Brazil
}

\author{
Thiago Alves Pinto* \\ University of Oxford \\ thiago.alvespinto@law.ox.ac.uk \\ Rodrigo Vitorino Souza Alves** \\ Federal University of Uberlandia \\ rodrigo@direitoereligiao.org
}

\begin{abstract}
The present article analyses cases from top Brazilian courts and has received contributions from several scholars, practitioners, and public officials to better understand the use of limitations to freedom of religion or belief in the country. The Brazilian Constitution provides for the right to freedom of religion or belief as a fundamental right, and other domestic legislation regulate the right, including those implementing international human rights treaties that Brazil has ratified. These laws are easily accessible. Nevertheless, domestic courts seldom rely on such international instruments or the case-law of international bodies in their judgments. Therefore, although these instruments are in force in Brazil, domestic courts do not expressly use or refer to the clauses of permissible limitations of the relevant international and regional human rights instruments, creating a scenario with low levels of legal certainty for those seeking the protection of the right to freedom of religion or belief.
\end{abstract}

\section{Keywords}

Brazil - human rights - freedom of religion or belief - limitation clauses

\footnotetext{
* Thiago Alves Pinto is a DPhil candidate in Law at the University of Oxford (UK) and a project coordinator for the Oslo Coalition on Freedom for Religion or Belief (Norway).

** Rodrigo Vitorino Souza Alves is a Professor of Law at the Federal University of Uberlandia (Brazil) and the Leading Scholar of the Brazilian Centre of Studies in Law and Religion.
} 
Brazil represents a compelling case in international human rights law and, more specifically, on issues related to freedom of religion or belief. On the one hand, the country plays a prominent role in international relations, as it is a Founding Member of the United Nations (UN) and remains active in the organisation. Brazil voted in favour of the Universal Declaration of Human Rights (UDHR) in 1948, ${ }^{1}$ despite disagreeing with the lack of references to the 'Biblical idea of the human having been created "in the image of God"' in the document. ${ }^{2}$ It has also ratified without reservations human rights treaties which provide for the protection of freedom of religion or belief, such as the International Covenant on Civil and Political Rights (ICCPR), ${ }^{3}$ and the American Convention on Human Rights (ACHR). Moreover, freedom of religion or belief is highly regarded in Brazil, as it is explicitly protected by the Constitution, ${ }^{4}$ and is also considered by the majority of Brazilians as a fundamental right. ${ }^{5} \mathrm{~A}$ report from the Pew Research Centre concluded that Brazil is one of the States with the fewest government restrictions and social hostilities, in relation to the manifestation of religion, among the world's 25 most populous countries. ${ }^{6}$

On the other hand, the Brazilian government seems to struggle to effectively incorporate international human rights standards from the documents mentioned above. The legislative branch has been slow to translate international treaties into domestic legislation and, in at least one instance, legislators have added more limitations to qualified rights than the ones set in international treaties, an issue which could affect freedom of religion or belief in the country. ${ }^{7}$ In addition, the Brazilian judiciary seems to pay little attention to international human rights law when deciding cases related to freedom of

1 Universal Declaration of Human Rights (UNGA Res 217 A (III)).

2 Heiner Bielefeldt, 'Philosophical and Historical Foundations of Human Rights', in Catarina Krause and Martin Scheinin (eds.), International Protection of Human Rights: a Textbook (Åbo: Åbo Akademi University Institute for Human Rights, 20o9), p. 5.

3 International Covenant on Civil and Political Rights (999 UNTS 171).

4 Constitution of the Federative Republic of Brazil (Adopted 5 October 1988), Art. 5 (VI).

5 Brian J. Grim and Roger Finke, The Price of Freedom Denied: Religious Persecution and Conflict in the Twenty-First Century (Cambridge: Cambridge University Press, 2010), p. 44.

6 Restrictions on religion among the 25 most populous countries, 2007-2015, Pew Research Center 12 April 2017, <www.pewforum.org/interactives/restrictions-on-religion-among-the -25-most-populous-countries-2007-2015/>, accessed 22 August 2019.

7 Thiago Alves Pinto, 'Offence to Religious Belief in International Human Rights Law' (DPhil thesis, University of Oxford, forthcoming). 
religion or belief, including those which have already been implemented in the legal system. ${ }^{8}$

Many authors have written about the importance of freedom of religion or belief in Brazil, ${ }^{9}$ yet little has been written on how courts have decided cases concerning limitations to this fundamental right. ${ }^{10}$ This article intends to investigate precisely this phenomenon. Therefore, the central question that this article will attempt to answer is the following: What is the legal rationale that top Brazilian Courts ${ }^{11}$ have employed in cases concerning limitations to freedom of religion or belief?

In order to answer this question, we will first present a brief background on freedom of religion or belief in Brazil, as this may be helpful in clarifying some issues regarding the relationship between international law and domestic law on this matter. Then, we will investigate the legal rationale that Brazilian courts have used to decide cases concerning freedom of religion or belief. The final substantive section will focus on specific questions about the relationship between freedom of religion or belief and other human rights. The article concludes with a summary of the findings, as well as some recommendations on how courts can better protect the right to freedom of religion or belief for everyone in Brazil.

8 See e.g. a case regarding the imposition of limitations to freedom of expression based on an abstract protection to religious beliefs decided by the São Paulo Court of Justice: TJSP, AP 99010085770-3, Apelação, 2010.

9 For a comprehensive study on Law and Religion in Brazil, see Alves, Rodrigo Vitorino Souza, 'Brazil' in Gerhard Robbers and W Cole Durham (eds.), Encyclopedia of Law and Religion (Leiden: Brill, 2016). See also Fábio Carvalho Leite, Estado e Religião no Brasil (Curitiba: Juruá, 2014); Priscilla Regina da Silva, Contrarreligião: Liberdade de Expressão e o Discurso de Ódio Contrarreligioso (Curitiba: Juruá, 2017); and Jayme Weingartner Neto, Liberdade Religiosa na Constituição: Fundamentalismo, Pluralismo, Crenças e Cultos (Porto Alegre: Livraria do Advogado, 2007).

10 There is one survey on the decisions of the Brazilian courts on freedom of religion or belief and religion-state relations, published in Portuguese by the Brazilian Centre of Studies in Law and Religion, which was the main source for this article: Alves, Rodrigo Vitorino Souza and others, A Liberdade Religiosa nos Tribunais Brasileiros: Legislação e Casos, (2018). [Religious Freedom in the Brazilian Courts: Legislation and Cases].

11 This article analyses several cases from Brazilian courts, most of them decided by the Supreme Federal Court (STF), Superior Court of Justice (STJ), Regional Federal Courts (TRFs), and Regional Courts of Justice (TJs). 
Several aspects have affected the implementation of freedom of religion or belief in Brazil and the subsequent manner in which courts have dealt with limitations to this right. In this section, we briefly explore four factors that play a role in this area; they are: historical background, social issues, legal framework, and the Brazilian relationship with international law. These factors are essential for the reader to understand the Brazilian context in relation to freedom of religion or belief, as well as to present probable reasons why the Brazilian judiciary seems reluctant to apply norms of international law in their rationale when deciding cases involving limitations to this right.

\subsection{Historical Background}

Brazil has been slow in acknowledging the importance of international human rights law in its legislation. This issue is exemplified by the fact that the ICCPR (adopted in 1966) and the ACHR (adopted in 1969), were just ratified in Brazil in 1992..$^{12} \mathrm{~A}$ likely explanation for the lack of action in this regard is due to the fact that between 1964-1985 Brazil was being governed by a military government, which paid lip service to international organisations, but was not interested in implementing civil liberties in the country. In this way, the right to freedom of religion or belief was present in the Constitution during the military dictatorship, but the military government could easily impose limitations on fundamental rights on grounds of protecting the 'public order and morals. ${ }^{13}$ Given this narrow interpretation of freedom of religion or belief, there was no right to conscientious objection during the military government. However, when democracy was re-established in Brazil in the '8os, a new Constitution was adopted, and it included freedom of religion or belief as a fundamental right. ${ }^{14}$ This insertion means that, in Brazil, freedom of religion or belief cannot be removed from the Constitution as a result of amendments. ${ }^{15}$

12 See онснв, Ratification Status for Brazil, UN, <http://tbinternet.ohchr.org/_layouts/ TreatyBodyExternal/Treaty.aspx?CountryID=24\&Lang=EN>, accessed 22 August 2019; and OAs, Current Status of Signatures and Ratifications of the Inter-American Treaties: Brazil, OAS, <www.oas.org/dil/treaties_signatories_ratifications_member_states_brazil .htm>, accessed 22 August 2019.

13 Constitution of the Federative Republic of Brazil (Adopted 24 January 1967, Amended 17 October 1969), Art. 150(6).

14 Constitution of Brazil, Art. 5 (Iv).

15 Ibid., Art. 6o(4); see also Aldir Guedes Soriano, Liberdade Religiosa no Direito Constitucional e Internacional (São Paulo: Juarez de Oliveira, 2002), p. 42. 


\subsection{Social Issues}

Brazil has a population of ca. 210 million people. According to the last official census, conducted by the Brazilian Institute of Geography and Statistics in 2010, 64.6 per cent are Roman Catholics, 22.2 per cent are Evangelicals, 8 per cent are not affiliated, agnostics or atheists ("no religion"), 2 per cent are Spiritists, and 3.2 per cent are members of other religious groups. ${ }^{16}$ Concerning religious aspects, Brazil is described by Grim and Finke as a 'rich mosaic of religious groups, ${ }^{17}$ which has constantly been changing in the past 25 years. According to a recent public opinion survey on religion in Brazil, there has been a significant shift in the national religious landscape, a migration from Catholic Christians to the Evangelical denominations and the "no religion" group. The survey also shows that 44 per cent of Evangelicals are former Catholics, as well as that Pentecostals and those with "no religion" are the two groups that had the highest growth in numbers. ${ }^{18}$ Although not an official survey, this is an important indicator of religious change, as demonstrated in the figure below:

\begin{tabular}{lcccc}
\hline & Aug. 1994 & Oct. 2005 & Jul. 2015 & Dec. 2016 \\
\hline Catholic & $75 \%$ & $66 \%$ & $55 \%$ & $50 \%$ \\
Pentecostals Evangelicals & $10 \%$ & $14 \%$ & $22 \%$ & $22 \%$ \\
Non-Pentecostals Evangelicals & $4 \%$ & $7 \%$ & $8 \%$ & $7 \%$ \\
Spiritism & $4 \%$ & $3 \%$ & $3 \%$ & $2 \%$ \\
Other religions & $2 \%$ & $3 \%$ & $5 \%$ & $5 \%$ \\
No religion & $5 \%$ & $7 \%$ & $7 \%$ & $14 \%$ \\
\hline
\end{tabular}

Evangelicals are often classified into Pentecostals (e.g. Assemblies of God, Universal Church of the Kingdom of God, Christian Congregation, Church of the Foursquare Gospel, Church of God, Brazil for Christ) and Non-Pentecostals (e.g. Baptists, Presbyterians, Methodists, Anglicans). The "no religion" group includes those who are believers but not affiliated, agnostics, and atheists. Spiritists are the followers of the spiritualistic teachings of Allan Kardec, and

16 See Censo 2010: número de católicos cai e aumenta o de evangélicos, espíritas e sem religião, IBGE, 29 June 2012, <https://censo2010.ibge.gov.br/noticias-censo?id=3\&idnoticia=2170\& view=noticia $>$, accessed 22 August 2019.

17 Grim and Finke, supra note 5, p. 109.

$1844 \%$ dos evangélicos são ex-católicos, Datafolha, 28 December 2016, <http://datafolha .folha.uol.com.br/opiniaopublica/2016/12/1845231-44-dos-evangelicos-sao-ex-catolicos .shtml >, accessed 22 August 2019. 
the "other religions" group includes among others African-Brazilian religions (Umbanda, Candomblé), indigenous religions, Hindus, Muslims, and Jews. Although this mosaic displays a majority of persons belonging to Christian denominations, Brazil has been relatively successful in protecting religious pluralism. ${ }^{19}$ However, this religious background has also affected the reasoning of some judges. In a recent decision, for example, a judge refused to recognise African-Brazilian beliefs and practices as a religion. ${ }^{20}$

\subsection{Legal Framework}

The Brazilian legal system is based on the civil law tradition, which means that codified laws are its primary source. In contrast with countries that follow a common law tradition, judicial opinions and legal precedents generally have a lower impact on judgements in Brazil. ${ }^{21}$ International law is intended to be universal, so it contains elements from both systems. Brazil successfully incorporated international human rights treaties into domestic law; nevertheless, decisions from supranational courts tend to be overlooked in most cases, as it is not part of the legal culture in Brazil to follow the case-law of such bodies.

In any case, as already mentioned, the Brazilian Constitution provides for freedom of religion or belief. ${ }^{22}$ Furthermore, since international treaties were translated and incorporated into domestic law, they also became statutory norms in Brazil. ${ }^{23}$ Other laws at federal and state level provide complementary protection for the right in question. ${ }^{24}$ Therefore, Brazil offers strong legislative protection for freedom of religion or belief.

\subsection{Brazil and International Human Rights Law}

As mentioned before, the relationship between Brazil and International Law is ambivalent. Brazil is a key international player, but what it has defended internationally is not always implemented in the country. One major issue concerning freedom of religion or belief was the country's inconsistency during the

19 Grim and Finke, supra note 5, p. 109.

$20 \quad 17^{\text {a }}$ Vara do Rio de Janeiro, No ooo4747-3320144025101, 2014.

21 The exception here is when a case is considered by top courts as an issue of "general repercussion", meaning that there are relevant economic, political, social or legal issues that exceed the subjective interests in the case. If the Court finds that there is general repercussion, the case is admitted by the Court and its final decision should be applied by lower courts in identical cases.

22 Constitution of Brazil, Art. 5 (VI-VIII).

23 The ICCPR became Pacto Internacional sobre Direitos Civis e Políticos (Decree No 592, Annex); in relation to the ACHR, see Convenção Americana sobre Direitos Humanos (Decree No 678, Annex).

24 For a comprehensive list see Soriano, supra note 15, pp. 213-238. 
discussions regarding the UN resolutions concerning the so-called 'defamation of religions'. There were several resolutions at the UN on this topic from 1999 until 2011. ${ }^{25}$ These resolutions were highly criticised, and even though some of the nomenclature was modified at times, the central ideas of the resolutions never changed. Brazil, however, was extremely contradictory when voting for these resolutions.

From 2001 until 2007, Brazil voted in favour of the resolutions and even expressed plans to expand already existing criminal laws prohibiting offence to religious feelings. ${ }^{26}$ Then it abstained from voting from 2008 until 2009. In 2010 it completely changed its position, as a representative asserted that the 'concept of defamation of religions was not consistent with international human rights law, and therefore with Brazilian legislation.27 This shift was undoubtedly a positive development. However, if the text of the resolutions did not change substantially, nor the Brazilian legislation on the topic, why did it take so long for Brazil to take a justified stance on the matter? The answer indicates that there is little understanding of what freedom of religion or belief truly encompasses.

Another issue concerning the relationship between Brazil and domestic law has to do with the implementation of international norms. Human rights are supposed to be enforced primarily by States. Consequently, if national laws are in line with international treaties, and judges are enforcing those laws, States would be fulfilling international human rights law norms even without any reference to such norms. The problem is when the State does not modify old legislation that might go against these norms. This is the case with Article 208 of the Brazilian Penal Code, which prescribes imprisonment of up to 1 year or a fine, for the following offences: 'To ridicule someone publicly, by reason of belief or religious capacity; to prevent or disrupt ceremony or practice of religious worship; to publicly vilify an act or an object of religious worship.' ${ }^{28}$ This Article combines three separate offences which can be judged separately. ${ }^{29}$

25 See Thiago Alves Pinto, 'A Critical Assessment of the United Nations Resolutions on Combating Defamation of Religions in the Light of International Human Rights Law' (Master Thesis, Åbo Akademi University, 2013).

26 GA, Report of the Secretary-General, Combating Defamation of Religions, (A/62/288), para. 9 .

27 GA, Third Committee, Summary Record of the 42nd Meeting, (A/C.3/64/SR.42), para. 7O.

28 'Escarnecer de alguém publicamente, por motivo de crença ou função religiosa; impedir ou perturbar cerimônia ou prática de culto religioso; vilipendiar publicamente ato ou objeto de culto religioso'. Brazil Penal Code (Decree No 2848), Art. 208 (unofficial translation).

29 Guilherme de Souza Nucci, Código Penal Comentado (9th ver. edn., São Paulo: Editora Revista dos Tribunais, 2009), p. 865. 
Two of those sections present no problem, but the first offence seems to lack the level of certainty required in criminal cases. 'To ridicule someone publicly, by reason of belief or religious capacity' can be interpreted broadly, and even though in order for the offence to take place specific intent is required, this is a somewhat vague limitation to freedom of religion or belief and freedom of expression. ${ }^{30}$

\section{3}

\section{Legal Rationale}

As Professor Bielefeldt wrote in his introductory article to this issue, 'Governments, in particular authoritarian governments, like to invoke limitations clauses to human rights in loose and unspecified ways, so as to claim broad leeway for themselves. Thus, they factually define the scope of people's FoRB, as they see fit. ${ }^{31}$ In this section, we intend to clarify whether or not this is the case in the Brazilian legal context by exploring three central questions. First, what are the criteria used by Brazilian courts to decide cases involving freedom of religion or belief? Second, are Brazilian Courts following international human rights guidelines or jurisprudence in cases concerning freedom of religion or belief? Third, what are the most common grounds invoked to limit freedom of religion in Brazil?

\subsection{Criteria Employed by Brazilian Courts to Decide Cases Involving Freedom of Religion or Belief}

Brazilian courts usually rely on various standards to decide cases involving freedom of religion or belief. The Constitution is the primary source for the decisions as it provides for fundamental rights. Human dignity, equality and non-discrimination, as well as the separation of religion and State (also called 'laïcité' or 'secularity' by the courts), are some of the principles that are usually invoked as the essential criteria for the decision-making. ${ }^{32}$ While there are no specific principles for deciding normative conflicts between fundamental rights in domestic law, proportionality and balancing are ideas or

3o Cesar Roberto Bitencourt, Código Penal Comentado (5 edn, São Paulo: Editora Saraiva, 2009), p. 790.

31 Heiner Bielefeldt, 'Limiting Permissible Limitation: How to Preserve the Substance of Religious Freedom', Religion and Human Rights 15:1-2 (2020), pp. 7-8.

32 See Alves, Rodrigo Vitorino Souza, 'Religion-State Relations and the Agreements Between the Federative Republic of Brazil and the Holy See', 2:2 Revista Latinoamericana de Derecho y Religión (2016), pp. 1-18. 
concepts present in several cases in which restrictions to fundamental rights, including freedom of religion or belief, are imposed.

In cases decided under previous constitutions, there were two specific grounds on which freedom of religion or belief could be restricted: 'public order and morals.' For example, in 1949 the Supreme Court found that the Brazilian Catholic Apostolic Church, a sectarian group of the Catholic Church, was violating the rights of the members of the Roman Catholic Church to manifest their beliefs. The sectarian group was established by a dissenting Catholic Bishop, and its ministers used the same symbols and dresses as the Roman Catholic Church. Although the church has not been dissolved nor prohibited from performing religious rites or services, its public masses were forbidden as they were regarded as an obstruction to and disrespect and disturbance of the Roman Catholic Church. According to the Court, this prohibition did not mean an interference with the right to freedom of conscience or belief of the members of the sectarian group, since this right is absolute, but only with freedom of manifestation of religion, which could be restricted on grounds of protecting public order and the rights of others. Therefore, the Court found that the practice of the Brazilian Catholic Church and its Bishop violated the freedom of manifestation of religion of the Roman Catholic Church's followers. ${ }^{33}$

In a second example, which was ruled in 1963, the Supreme Court stated that the use of police force to stop the exercise of a religious service was legitimate when a religious practice violated the public order and morals. In this case, the religious practice was spiritual healing in a Pentecostal Church, which the Court regarded as a practice aimed at misleading the humble people of the city. ${ }^{34}$

In 1981 the Supreme Court stated that freedom of religion or belief could not be restricted except for acts that are offensive to the public order and morals. In this case, the fact that a person was subject to criminal sanctions could not be understood as the authorisation to limit religious freedom in itself. The prohibition of attending religious services in private or public spaces may not be a requirement for suspended prison or jail sentences. ${ }^{35}$

Finally, the Supreme Court did not allow a change in the time in relation to the voting day, which was scheduled to happen from 8 AM to 5 PM on Saturday, 15 November 1986 (currently, the voting day is always on Sundays). The Court considered that such change would create unlawful discrimination in favour of Sabbath-keepers, violate the separation of religion and State, as well as

33 STF, MS 1114 (Mandado de Segurança) 1949.

34 STF, RMS 16857 (Recurso em Mandado de Segurança) 1963.

35 STF, RE 92916-9 (Recurso Extraordinário) 1981. 
favour the interests of members of minority religious groups over those of the general population. ${ }^{36}$

\subsection{The Application of International Human Rights Guidelines on Freedom of Religion or Belief by Brazilian Courts}

Concerning the use of international human rights guidelines or jurisprudence, Brazilian courts rarely cite international legal instruments, or the case-law of international bodies, or soft-law concerning freedom of religion or belief, ${ }^{37}$ in their judgments. In individual opinions contained in the decisions, some judges have mentioned international instruments in passing, but they have not been decisive in their judgements. ${ }^{38}$ The absence of references to international law is a noteworthy finding, since Brazil has ratified most of the international and regional human rights instruments in the ' 9 os. Consequently, even though these instruments are in force in Brazil, courts do not expressly refer to the clauses of permissible limitations of the relevant instruments. Decisions are mostly based on national law and the characteristics of each case.

A few exceptions worth mentioning are the Supreme Court and the National Council of Justice (the highest administrative body of the Judicial branch) decisions which have referred to cases from the European Court of Human Rights, such as $S A S$ v. France, ${ }^{39}$ Lautsi v. Italy, ${ }^{40}$ Chappell v. The United Kingdom, Valsamis and Efstratiou v. Greece, Tsirlis and Kouloumpas v. Greece, and Thlimmenos v. Greece. ${ }^{41}$ In sum, despite the existence of criteria for limitations to freedom of religion or belief in national legislation based on international human rights instruments, and few references to international jurisprudence, Brazilian courts have rarely used these standards in decisions concerning the right in question.

36 STF, RP 1371 MC (Medida Cautelar na Representação) 1986.

37 See e.g. Human Rights Committee, CCPR General Comment No. 22: Article 18 (Freedom of Thought, Conscience or Religion), (CCPR/C/21/Rev.1/Add.4); and Human Rights Council, Rabat Plan of Action on the prohibition of advocacy of national, racial or religious hatred that constitutes incitement to discrimination, hostility or violence, (A/HRc/22/17/Add.4, annex, appendix).

38 See e.g. STF, ADI 4439 (Ação Direta de Constitucionalidade) 2018.

39 STF, RE 859376 RG (Repercussão Geral no Recurso Extraordinário) 2017, no decision on merits yet.

40 CNJ, PP 1344, 1345, 1346, and 1362 (Pedidos de Providências) 2007; CNJ, PP oooo620 8520132000000 (Pedido de Providências) 2016.

41 CNJ, PP ooo3657862014200000o (Pedido de Providências) 2014. 


\subsection{Common Grounds Invoked to Limit Freedom of Religion or Belief in Brazil}

Concerning the grounds invoked to limit freedom of religion in Brazil, one of the most important for the restriction of religious freedom is the principle of separation of religion and State (also referred to as the separation clause, Article 19 of the Constitution). The "rights of others" is another ground frequently invoked, but this will be analysed in more detail in the next section. In addition to the National Council of Justice, domestic courts have given their interpretation on the concept of 'laïcité', in judgments dealing with the relationship between religion and State, as explained in the following paragraphs.

In a case concerning an anencephalic foetus-in which the Supreme Court decided whether pregnant women in this situation would have the right to abortion - there was an amicus curiae intervention by the National Conference of Catholic Bishops which was rejected by the Court because of the laïcité of the State. ${ }^{42}$ However, the same institution was allowed to be one of the amicus curiae in other cases, such as a case concerning embryonic stem cells, in which the Supreme Court authorized the use of cells derived from embryos developed from eggs that have been fertilised in vitro, and which were are going to be discarded after three years of frozen storage. ${ }^{43}$

Laïcité was also the ground for a decision by the Superior Court of Justice on accommodation of religious beliefs. A man was refused to join the army because he had not participated in the physical exam required for those interested. He alleged that he could not have undertaken the exam on Saturday, as it would go against his religious beliefs. The court decided that the laïcité of the State does not allow treating citizens differently on grounds of religious belief, whether in a positive or negative way. ${ }^{4}$

The separation of religion and the State is also one of the reasons why tax exemptions (Article 150, VI, b of the Federal Constitution) are granted not only to the religious temples but also to the other properties belonging to religious communities. For the Supreme Court, the State cannot charge taxes from religious communities and their properties because it could restrict the exercise of religious services. In spite of that, exemptions would not apply if the activities developed by the religious community bring risks to the market. ${ }^{45}$ In a case concerning an Anglican Cemetery, for example, the Court confirmed that cemeteries connected to religious institutions should be protected by the tax

\footnotetext{
42 STF, ADPF 54 (Arguição de Descumprimento de Preceito Fundamental) 2004.

43 STF, ADI 3510 (Ação Direta de Inconstitucionalidade) 2008.

44 STJ, ROMS 22825 (Recurso Ordinário em Mandado de Segurança) 2007.

45 STF, RE 325822 (Recurso Extraordinário) 2002.
} 
exemption clause, as long as they are non-profit cemeteries and exclusively dedicated to performing religious and funeral services. ${ }^{46}$

However, the scope of the separation of religion and State is still highly controversial. For example, the Superior Court of Justice has ruled that when the State supports the construction of a Catholic temple, it does not violate the separation clause. The two main reasons for that interpretation-which are undoubtedly weak but still accepted by domestic courts - are that Brazil is a religiously plural country where religion is an important part of its history and culture, and that laïcité does not mean that the State should be hostile to religions. ${ }^{47}$

Recently, the Supreme Court ruled that the teaching of a particular religious doctrine in public schools does not violate the Constitution. Religious education is required by the Constitution to be offered in public schools as an elective course (Article $210 \S 1$ ). However, neither the Constitution nor other legislation regulate the content of that course, a matter of great controversy for the past 30 years in Brazil. In September 2017, the Supreme Court decided the case, affirming the constitutionality of denominational religious education as an elective course of the public elementary school's curriculum. For the Court, Brazilian laïcité does not prevent religious education in public schools, and the constitutional requirement that it should be optional harmonises the separation clause with freedom of religion or belief. Moreover, the State is not allowed to artificially create its own religious teaching and prevent the hierarchisation of the religious doctrines. Finally, the Supreme Court stated that religious education should be offered on equal terms in relation to the plurality of religions and beliefs. ${ }^{48}$

Laïcité, however, is not the only criteria adopted for solving cases of religionstate relations, the principle of equality is also often invoked in these cases. Equality was one of the main reasons for granting to an Evangelical community the right to use an airport for a religious event. According to the Superior Court of Justice, the government may exceptionally allow the use of public buildings that are characterised by a special use or aim for religious events. Consequently, the Court understood that the discussion about the use of this kind of public space was related to administrative norms, not freedom of religion or belief, since that location was not a religious temple. Moreover, despite recognising that there was no right to use that building for an evangelical conference (with one million attendees), the Court also found it should grant the

46 STF, RE 578562 (Recurso Extraordinário) 2008.

47 STJ, REsp 951868 (Recurso Especial) 2008.

48 STF, ADI 4439 (Ação Direta de Constitucionalidade) 2018. 
same treatment given to the Catholic Church, as it was the place used to host an event with Pope John Paul II. The Court also mentioned that exceptionally allowing a different use of the airport would be similar to allowing stadiums to host religious events and artistic presentations, as well as allowing artistic exhibitions at the Superior Court of Justice. ${ }^{49}$

From a different perspective, equality was the grounds on which the Supreme Court rejected a claim for accommodation. For the Court, allowing Jewish students to take the National High School Exam, the most important entrance examination of higher education in Brazil, on a day or time other than the Sabbath would violate the right to equality and creates an unlawful privilege to a particular religious group. ${ }^{50}$ In a similar case, the Superior Court of Justice refused the accommodation claim of an Adventist who, based on the right to freedom of religion, required to take an exam to the career of Magistrate on a day other than Saturday. ${ }^{51}$ The claim of an Adventist concerning the public exam to the Military Police was rejected by the Court on the same grounds, stating that freedom of religion cannot create situations of differential treatment between people (i.e. favouritism or persecution), in relation to the other candidates that do not profess the same religion. ${ }^{52}$

\section{4}

\section{Competing Rights}

While we share some of the concerns regarding the language of "balancing" pointed out by Bielefeldt, ${ }^{53}$ Brazilian courts still use this term when dealing with competing rights. While this technique should never be the first step in imposing a limitation, courts tend to apply this procedure when the ground for restricting the manifestation of beliefs is to protect the rights of others. As mentioned above, freedom of religion or belief is as a fundamental right in the Brazilian context; however, what happens when there is a conflict between freedom of religion or belief and other fundamental rights?

A fundamental right that has been balanced against freedom of religion or belief is the right to life. In 1993, the Superior Court of Justice analysed a case in which the parents, who were Jehovah's Witnesses, refused to authorise a blood transfusion to their adolescent daughter, who subsequently died of a sickle cell

49 STJ, AgRg no MS 5407, (Agravo Regimental no Mandado de Segurança 199700641953) 1997.

$5^{\circ}$ STF, Ag Reg na sta 389 (Agravo Regimental na Suspensão de Tutela Antecipada) 2010.

51 STJ, RMS 16107 (Recurso em Mandado de Segurança) 2005.

$5^{2}$ STJ, RMS 22825 (Recurso em Mandado de Segurança) 2007.

53 Bielefeldt, supra note 31 . 
crisis in a hospital. Thus, the Court was called to balance the right to life and the best interests of the teenager on the one hand, and the freedom of religion or belief as well as the autonomy of the will, on the other hand. The refusal, based on their religious beliefs, was encouraged by a doctor, who was a friend of the family and also a Jehovah's Witness. The Court decided that due to her medical condition and imminent danger to life, the hospital and doctors should have performed all the necessary procedures, including blood transfusion, despite the inexistence of parental authorisation - they had an ethical and legal duty to save her life. This decision, however, meant that the parents could not be convicted of a crime (homicide) since they took their daughter to the hospital and their declaration of consent was deemed unnecessary by the Court in that situation. ${ }^{54}$ However, a lower Court upheld the conviction of the doctor who encouraged the family to avoid blood transfusion by a jury trial, based on the violation of his ethical and legal duties as a doctor. The Superior Court of Justice denied his petition of habeas corpus due to the complexity of the matter, although reasoning in favour of his criminal liability. ${ }^{55}$ Furthermore, the Superior Court of Justice and the Supreme Court refused to consider his case under special and extraordinary appeals. ${ }^{56}$

A couple of years after the promulgation of the new Constitution, the Superior Court of Justice balanced the fundamental rights to freedom of conscience and religion with the right to public health. Charlatanism and spiritual healing ('curandeirismo') — practices declaring miraculous healings using substances, gestures, or words - are prohibited by the Brazilian Penal Code as crimes against public health. However, the Court found that the unity of the legal system does not admit logical contradictions, meaning that laws may not prohibit and consent at the same time. As the Constitution separates religions and the State, as well as protects the freedom to believe and to manifest the beliefs in the form of religious celebrations, procedures and rituals; each person has the freedom to choose a religion, which should be understood as the communication of a person with the divine being. Therefore, the fundamental right to freedom of conscience and religion should protect members of those religions who believe in spiritual healing. ${ }^{57}$ This judgement reached

\footnotetext{
54 STJ, HC 268459 (Habeas Corpus) 2014.

55 STJ, HC 7785 (Habeas Corpus) 1998. After the 2014 judgement in favour of the parents, he presented a new petition, which was refused again by the Court in STJ, PExt no HC 268459 (Pedido de Extensão no Habeas Corpus) 2015.

56 STJ, AgRg no ARs 182531 (Agravo Regimental no Agravo em Recurso Especial) 2012; and STF, ARE 745979 (Recurso Extraordinário com Agravo) 2014.

57 STJ, HC 1498-3 (Habeas Corpus) 1992.
} 
the opposite conclusion compared to the case mentioned before concerning spiritual healing in Pentecostal Church. ${ }^{58}$

The Superior Court of Justice also ruled that using loudspeakers to share information about a church is not unlawful. Religious institutions and their temples are not excluded from the rules concerning the volume limits as established by law, as argued by those who have accused religious communities of disturbing the peace of the community, yet the Court did not accept the argument of the applicant in the case in question. One of the main reasons mentioned by the Court for its verdict was that the vast majority of the population around the church did not feel uncomfortable with the use of loudspeakers for religious purposes and even supported their use. ${ }^{59}$

The limits of freedoms of artistic expression vis-à-vis freedom of religion or belief were analysed by the Supreme Court in 2014. In this case, an adult magazine presented a naked woman wearing a Christian symbol (a rosary). Although the Court excluded this kind of publication from the protection of freedom of the press, it found a conflict between freedom of artistic expression and the protection of religious feelings of others, thus concluding that the restriction of freedom of artistic expression was necessary for the protection of religious feelings. ${ }^{60}$ Even though no general repercussion was attributed to the case by the Supreme Court, meaning that the decision is only applicable in the instant case, ${ }^{61}$ it is an important precedent for the evaluation of conflicts between freedom of expression and freedom of religion. However, it must be highlighted that the protection of religious feelings is not present in the Constitution, only freedom of conscience and religion is.

Lower Courts have decided on similar issues. A branch of the Court of Justice of the State of Sao Paulo ruled twice in 2015 that the videos of a humoristic group satirising religious beliefs shall not be removed from the internet. An evangelical leader and politician required the videos to be removed from YouTube, arguing that more than 80 per cent of the Brazilian population was Christian and would be disturbed by the videos, thus an alleged violation of Article 208 of the Criminal Code. ${ }^{62}$ However, the Public Prosecutor's Office understood that there was no intention to commit a crime and that freedom of expression shall only be limited in extraordinary circumstances,

\footnotetext{
58 STF, RMS 16857 (Recurso em Mandado de Segurança) 1963.

59 STJ, REsp 951868 (Recurso Especial) 2008.

6o STF, ARE 790813 RG (Repercussão Geral no Recurso Extraordinário com Agravo) 2014.

61 See supra note 21.

62 'To ridicule someone publicly, by reason of belief or religious capacity; to prevent or disrupt ceremony or practice of religious worship; to publicly vilify an act or an object of religious worship' (unofficial translation).
} 
and for this reason, the case was closed. In the second of these two cases, the Public Prosecutor affirmed that the '[f]reedom of expression should only be restricted in extreme situations, in order to protect another fundamental right. As there is no incitement to hatred or ridicule of believers in the video, it does not characterize offence to the dignity of Christians. ${ }^{63}$

Recently, a Catholic institution required payment of compensation from the same comedy group for the humoristic videos that mock the Catholic Church and its beliefs, on grounds of violating Catholics' freedom of conscience, religious freedom, and their alleged right to the protection of religious feelings. The religious institution also mentioned the case of Otto Preminger-Institut v. Austria (ECtHR) in the complaint. However, the branch of the Court of Justice of the State of Rio de Janeiro closed the case due to lack of payment of the court costs by the religious institution. ${ }^{64}$ In all these cases, the petitioners affirmed that the humoristic group committed the crime prohibited by Article 208 of the Criminal Code. However, the Criminal Code does not protect groups or ideas, as pointed out in Section 1 of the article. ${ }^{65}$

Similarly, in a case that is still pending before the courts, a judge prohibited in 2017 the showing of a play called "The Gospel According Jesus, Queen of Heaven", which portrays Jesus Christ as a transgender woman in the present day. The play proposed to recount biblical passages from a contemporary perspective and reflected on the oppression and intolerance suffered by transgender people and minorities in general. However, for the judge of the branch of the Court of Justice of Sao Paulo, religious figures and symbols cannot be exposed to ridicule, and the show would offend the feelings of ordinary citizens. The judge decided that freedom of expression should not be used for aggression and lack of respect. ${ }^{66}$

In a different case concerning persons belonging to the LGBTI community, another branch of Court of Justice of Sao Paulo examined the claim for indemnification made by a transgender person who staged the crucifixion during an LGBT parade, with a saying on the top of the cross: "stop homophobia". An Evangelical pastor and politician, feeling offended by the scene, made several comments against her, allegedly associating her image with religious intolerance and disrespect for religion. The judge, however, rejected the claim of the

63 PRR2 arquiva inquérito sobre vídeo do Porta dos Fundos, MPF, 1 December 2015, <www .mpf.mp.br/regiao2/sala-de-imprensa/noticias-r2/mpf-arquiva-inquerito-sobre-video -do-porta-dos-fundos>, accessed 22 August 2019.

64 TJRJ, Processo no 0155164-5720178190001, 2018.

65 See Section 2.4 supra (Brazil and International Human Rights Law).

66 TJSP, Processo no 1016422-8620178260309. 
pastor, saying that the exercise of freedom of expression corresponds to the duty to bear popular and unpopular artistic expressions. ${ }^{67}$

Regarding crimes committed against religious groups, the Superior Court of Justice has affirmed that the distinction between the crimes of religious discrimination and insult lies in the volitional element of the agent. If the intention is to offend an indeterminate number of people, or even to draw a derogatory profile of all the attendants of a certain religious group, the crime will be of religious discrimination (which is an interpretation of Article 20 of Law 7.716/1989). ${ }^{68}$ However, if the objective is only to attack one's honour, using one's religious beliefs as a means of intensifying the offence, then the crime is characterised as insult (Article 140 § 3 , of the Brazilian Penal Code). ${ }^{69}$

A recent example concerns the founder of the major charismatic Roman Catholic movement in Brazil. This case might become one of the most important precedents on the subject. The priest was accused of practising the crime of discrimination after he published a book instructing the Catholic community to "rescue" people from Spiritism and African-Brazilian religions (described as works of the devil) for their salvation. The Court stated that his discourse was an act of proselytism, which is practised by most of the world religions and is protected by the fundamental right to freedom of religion, as one of the elements of its core. In the view of the Court, religious freedom and freedom of expression are some of the foundations of the constitutional order but should be exercised with respect to other fundamental rights. Therefore, those rights do not protect unlawful discrimination nor incitement to violence or discrimination. Freedom to manifest religious beliefs (especially in the case of religions with universal intentions) embraces the proselytising discourse, meaning that to persuade the other, it is not unlawful to compare religions. This fundamental right even protects speech that considers a certain religion superior to other religions and those discourses that generate animosity. For the Supreme Court, this kind of expressions shall only be regarded as a criminal offence if it (i) affirms inequality (cognitive stage); (ii) affirms superiority (axiological stage); and (iii) affirms domination, exploitation, elimination, suppression, reduction of fundamental rights of individuals belonging to the other religious group (legitimacy stage). Thus, the Court does not consider it a criminal offence to utter that religions are not equal, or that they do not have the same moral value, or

67 TJSP, Processo no 1061405-892015826010o, 2016.

68 'Practice, induce or incite discrimination or prejudice of race, color, ethnicity, religion or national origin. Penalty: imprisonment of one to three years and a fine' (unofficial translation).

69 STJ, APn 612 (Ação Penal) 2012. 
even that one religious belief is superior to others. The crime exists only if the speech also affirms that it is legitimate to practice discrimination or violence (e.g. domination or exploitation) against the believers or followers of the religion or belief that is regarded as inferior. ${ }^{70}$ Therefore, despite not following international guidelines, the Court has provided a sensible test to address potential conflicts concerning the same subject matter.

While determining the conformity of a limitation to freedom of religion or belief with international human rights law, courts should always consider first that persons are entitled to the full exercise of the right. Limitations should always be exceptional and, as Bielefeldt asserted, 'any restrictions must meet a number of criteria and must be connected with the provision of legal remedies available to everyone who think their rights have inappropriately been infringed upon. ${ }^{71}$ The present article has investigated the legal rationale that top Brazilian Courts have employed in cases concerning limitations to freedom of religion or belief and whether they follow the precepts mentioned above.

As demonstrated in this article, Brazilian courts often ignore international human rights treaties as a whole, even those enshrined in domestic legislation. Consequently, the rationale developed to restrict freedom of religion or belief has been mostly based on the Constitution. This is not problematic in itself, as the Brazilian Constitution provides for a robust protection of the right to freedom of religion or belief. The main problem is that some of the constitutional reasons provided for restricting the right to freedom of religion or belief are based on principles such as laïcité, but not on the strict test provided for in Article 12.3 of the ACHR and Article 18.3 of the ICCPR. These tests would likely lead to greater objectivity and rationality in decision-making. That does not mean that the principle of laïcité is not important; it obviously is. The main problem lies in the fact that it is a malleable principle, which can be used to impose several restrictions on freedom of religion or belief. Furthermore, the application of this principle by courts is not consistent, as a decision has even allowed the State to fund the construction of a religious temple. While it is

\footnotetext{
70 STF, RHC 134682 (Recurso Ordinário em Habeas Corpus) 2016.

71 Heiner Bielefeldt, 'Freedom of Religion or Belief-A Human Right under Pressure' 1:1 Oxford Journal of Law and Religion (2012), p. 22.
} 
correct to affirm that laïcité does not mean that the State should be hostile to religions, ${ }^{72}$ it surely does not mean the State can privilege one religious group alone.

Finally, concerning clashes between competing rights, in most instances the courts have not relied on international law guidelines, nor developed their own system to deal with such cases. Naturally, this creates a scenario with low levels of legal certainty for those seeking the protection of the right to freedom of religion or belief, as well as other rights. The remarkable exception in this area was the test elaborated by the Supreme Court to decide on potential conflicts between freedom of religion or belief and freedom of expression. However, this case also represents a missed opportunity for the Court to find a solution in international guidelines, such as the Rabat Plan of Action, which would demonstrate that the Court is willing to engage in a global dialogue on the issue. Therefore, we conclude that members of the judiciary in Brazil would benefit substantially from more training concerning the right to freedom of religion or belief.

\section{Acknowledgements}

During its elaboration, the article received contributions from several scholars, practitioners, religious groups, NGOs, and public officials as the authors discussed issues related to the article in several meetings, seminars, discussion panels, and interviews, most of them organised by the Brazilian Centre of Studies in Law and Religion. The input received at these events is reflected in this document. We would like to thank specially Jayme Weingartner Neto, Priscilla Regina da Silva, José Renato Venâncio Rezende and Stefanie Schegoscheski Viotto Ferraz for their contributions to this article.

72 STJ, REsp 951868 (Recurso Especial) 2008. 